\title{
Biodiesel Production from Waste Sunflower Oil and Engine Performance Tests
}

\author{
Sedef Köse ${ }^{1}$, Gizemnur Aylanşık ${ }^{1}$, Mustafa Babagiray ${ }^{2 *}$, Tolga Kocakulak ${ }^{3}$ \\ 0000-0002-1562-1403, 0000-0002-3769-0389, 0000-0002-2482-6662, 0000-0002-1269-6370 \\ ${ }^{2}$ Automotive Engineering Department, Faculty of Technology, Afyon Kocatepe University, Afyonkarahisar, 03200, Turkey \\ ${ }^{3}$ Electricity and Energy Department, Vocational High School of Technical Sciences, Burdur Mehmet Akif Ersoy University, Burdur,
}

${ }^{1}$ Automotive Engineering Department, Faculty of Technology, Gazi University, Ankara, 06500, Turkey 15030, Turkey

\begin{abstract}
In this study, biodiesel is produced from waste sunflower oil and its effect on engine performance and specific fuel consumption is experimentally investigated. Transesterification method was used in biodiesel production of waste sunflower oil. After production, analyzes giving characteristics of biodiesel such as density, kinematic viscosity, sulfur and water content were made. As a result of the analysis, the biodiesel fuel with a viscosity of $4,372 \mathrm{~mm}^{2} / \mathrm{s}$, which has a reaction temperature of $60^{\circ} \mathrm{C}$, an alcohol content of $25 \%$ and a catalyst ratio of $0.05 \%$, was chosen as a reference fuel, as it was observed to comply with European Standards of EN 14214. Standard diesel fuel was taken as reference for the purpose of examining the effect of biodiesel on engine performance. Performance and fuel consumption tests of the produced biodiesel and standard diesel fuel were carried out at the full load position at seven different engine speed levels. Experiments were carried out on a single cylinder four-stroke Cussons P8160 engine. As a result of the test, it was observed that there was a $7.06 \%$ reduction in engine moment compared to the standard diesel fuel use of B 100 fuel. In addition, compared to the standard diesel fuel of B100 fuel, there was a $6.64 \%$ reduction in engine power. Specific fuel consumption values for B100 and diesel fuels at $2200 \mathrm{rpm}$ engine speed were $426.75 \mathrm{~g} / \mathrm{kWh}$ and $355.22 \mathrm{~g} / \mathrm{kWh}$, respectively.
\end{abstract}

Keywords: Biodiesel; Engine performance test; Sunflower oil; Transesterification

\author{
* Corresponding author \\ Mustafa Babagiray \\ mbabagiray@aku.edu.tr \\ Adress: Automotive Engineering De- \\ partment, Faculty of Technology, \\ Afyon Kocatepe University, Afyon- \\ karahisar, Turkey
}

Tel:+902722182543

Fax: +902722182693

Research Article

Manuscript

Received 16.07.2020

Revised $\quad 04.09 .2020$

Accepted $\quad 07.09 .2020$

Doi: 10.30939/ijastech..770309

\section{Introduction}

The need for sustainable energy sources is increasing rapidly due to the increase in the world population, industrialization and transportation demands. With the increase in energy use, there is a risk of exhaustion in fossil fuel (natural gas, oil, coal, etc.) reserves where most of the energy needs are met. In addition, increases in petroleum-derived fuel prices and high emissions are observed. The depletion of fossil fuel reserves leads researchers, manufacturers and scientists to seek new technologies, alternative fuels and renewable energy sources. Many methods have been used in the research and development of alternative energy sources, and biomass energy is of great importance among these methods $[1,2-4]$.

Biodiesel is the sub-branch of the biomass energy class and is a renewable energy source that can be produced from waste, animal and vegetable oils for use in diesel engines [5].
Waste biodiesel may be used in compression ignition engines and systems without any structural changes or additional systems [6, 7]. However, in the experiments, it has been noticed that with the use of biodiesel in pure form, problems such as carbon accumulation in the injector tip, dilution of the lubricant, excessive amount of engine deposits and wear in the cylinder liner occur. The use of biodiesel by mixing with petroleum-based diesel fuel is preferred in order not to decrease engine life. The use of biodiesel as pure fuel is called B 100, and its mixing by volume is used as B (biodiesel concentration ratio) [21]. Differences can be seen according to the effect of using biodiesel in pure or mixed form on engine performance and emissions, technical characteristics of the engine and test equipment under test, raw material of the biodiesel, engine operating conditions and diesel fuel properties [8].

Due to its many advantages, research on the production of 
biodiesel and its use on internal combustion engines is gaining importance. The biodiesel fuel contains approximately $11 \%$ oxygen in its chemical structure. Therefore, it has a lower power density than petroleum-based diesel fuel. Biodiesel use emits lower hydrocarbon (HC), carbon monoxide (CO) and particulate (PM) emissions than fossil fuels, and an increase in nitrogen oxide $\left(\mathrm{NO}_{\mathrm{x}}\right)$ and carbon dioxide $\left(\mathrm{CO}_{2}\right)$ emissions are observed. Biodiesel fuel has higher viscosity than petroleum based fuel atomization of the fuel sent into the cylinder is lower than petroleum based fuel. It is safer because of the higher flash point of biodiesel [7,9-12]. Since cetane number is higher than petroleum based diesel fuel, it provides engines to work with less knock [21]. It also has a better lubricant feature in the engine and is effective in extending engine life. Because of its better lubrication, it reduces engine wear by $65 \%$ even when it is used instead of $1 \%$ diesel [24].

Four different methods are used in biodiesel production. These methods are; dilution (thinning), micro-emulsion, pyrolysis and transesterification. The most widely used method of these methods is the transesterification. Transesterification is the formation of biodiesel as a result of reaction of vegetable and animal oils with alcohol. Ethanol and methanol are generally used as alcohol. The transesterification method is frequently preferred due to its high renewability, low cost, lighter reaction conditions, ease of production at an industrial scale and its characteristics close to standard diesel fuel. Despite these advantages, there are also disadvantages such as extensive separation and cleaning processes, the risk of side reactions and a large amount of water waste $[6,13,14]$.

Pullen et al. tested biodiesel fuel in diesel engine. They observed that the use of biodiesel increased fuel consumption by around $14 \%$ [15]. Akay experimented with a single cylinder and direct injection diesel engine (B30) by mixing biodiesel obtained from waste vegetable oils using the transesterification method with diesel fuel (B30). According to the load characteristics obtained, the use of biodiesel reduced the thermal efficiency by 1-5\% [16]. Rahman et al. investigated the properties of biodiesel-diesel mixtures, engine performance, emission characteristics and environmental-economic effects of biodiesel production, the effects of this mixture on the engine. They reported that mixtures containing up to $30 \%$ biodiesel have almost the same properties as diesel. Compared with diesel, they have shown that the biodieseldiesel blend provides a shorter ignition delay and a low rate of heat release and provides a slightly higher efficiency by sacrificing a small amount of fuel. They found that the emissions of $\mathrm{HC}, \mathrm{CO}$ and $\mathrm{PM}$ are greatly reduced, but $\mathrm{NO}_{\mathrm{x}}$ emissions are slightly higher [17]. Çat stated that the biodiesel produced from waste vegetable oils creates lower emissions and is used as an alternative fuel in the standard diesel engine. According to the results of the experiment, it was found that the use of biodiesel in the diesel engine did not cause a noticeable loss of performance, reduced $\mathrm{HC}, \mathrm{CO}$ and soot emissions and increased $\mathrm{NO}_{\mathrm{x}}$ emission and specific fuel consumption [18]. Soysal experimentally examined the effects of adding biodiesel to petroleum diesel fuel on engine performance characteristics. Soysal determined with the use of biodiesel and biodiesel - diesel fuel mixtures in the experimental results, the average effective pressure, moment and effective power values decreased by $1 \%$ to $3 \%$ compared to the use of pure diesel fuel, and the specific fuel consumption increased between $4 \%$ and $13 \%$ [19]. Nişancı et al. performed a motor performance test using fuels produced from canola, soy and sunflower oil in volumetrically different mixing ratios in a direct injection diesel engine [20]. Özsezen obtained biodiesel using palm waste sunflower oil. He tested the fuel obtained in a standard diesel engine. He determined that biodiesel blends caused an increase in specific fuel consumption. According to the results of the experiment, due to the fact that the biodiesel contains oxygen, it has determined that there is a decrease in smoke density, $\mathrm{HC}$ and $\mathrm{CO}$ emissions. However, biodiesel determined that nitrogen oxide $\left(\mathrm{NO}_{\mathrm{x}}\right)$ emission increased [21]. In his study, Dinçbaş investigated the effects of the biodiesel produced from soybean oil on the engine if it was used for a long time in the diesel engine. $\mathrm{He}$ observed that as a result of the use of soy methyl ester, the engine moment and engine power decreased by $2.04 \%$ and $1.98 \%$, respectively. It determined that there was an increase of $13.07 \%$ in specific fuel consumption [22]. Kaya used biodiesel produced using canola oil by mixing it with diesel oil of petroleum origin. He carried out an experiment by accepting the other parameters of the engine as constant at different spray pressures. With the increase in the rate of biodiesel contained in fuel, it has determined that there is an increase in specific fuel consumption, carbon dioxide and nitrous oxide emissions. Also, with the increase of the biodiesel ratio in the mixture, it was determined that effective yield, carbon monoxide, hydrocarbon and soot emissions decreased. He observed that effective efficiency decreased and fuel consumption increased in both cases when the spray pressure was increased or decrease [23]. Alptekin et al. tested biodiesel produced from animal oils with diesel fuel of petroleum origin in diesel engine. He observed that the specific fuel consumption in biodiesel use was about $16 \%$ higher. He observed that the maximum cylinder pressure increased $1.2 \%$ on average compared to diesel, $\mathrm{CO}$ emissions decreased, and $\mathrm{CO}_{2}$ and $\mathrm{NO}_{\mathrm{x}}$ emissions increased [24]. Tillem produced biodiesel from cotton oil, waste sunflower oil and canola oil. He added $20 \%$ of the different fuels he produced to diesel fuel by volume. He studied exhaust emission values and engine performance characteristics under different operating conditions. He observed that when he mixed the biodiesel fuel he obtained with $20 \%$ oil with petroleum origin, it could be used without any change in the engine. He further noted that when the mixture was used in the engine, it was not necessary to additionally preheat the fuel [25].

In this study, biodiesel was produced from waste sunflower oil by transesterification method. The production stages of biodiesel fuel were examined in detail and analyzes 
were carried out to determine the properties of the produced biodiesel fuels. As a result of the analyzes, reference fuel was determined within the framework of EN 14214 Biodiesel European Standards. Experiments were carried out under different conditions by using pure biodiesel fuel (B100) in a single cylinder, direct injection, compression ignition engine. In the experimental results, the comparison of the engine speed characteristics and specific fuel consumption results obtained with biodiesel fuel and standard diesel fuel was made.

\section{Material and Method}

Within the scope of this study, 27 different biodiesel were produced by changing the parameters of temperature, catalyst ratio and alcohol rate by using transesterification method from waste sunflower oil. The reason for choosing the transesterification method as the production method is that the fuel produced has a high cetane number, low emission values, and the production is suitable for laboratory conditions.

The reason for the use of waste sunflower oil for the production of biodiesel is that it is easily available and there is a need for recycling. The effect of the optimum fuel among the produced biodiesel fuels on engine performance and specific fuel perfection was investigated.

\subsection{Biodiesel production}

Transesterification method was used for the production of biodiesel from waste sunflower oil. This method consists of 6 steps of mixing alcohol and catalyst, reaction, separation, removal of alcohol, neutralization of glycerin and washing of methyl ester. The stages of biodiesel production with the transesterification method are shown in Fig. 1.

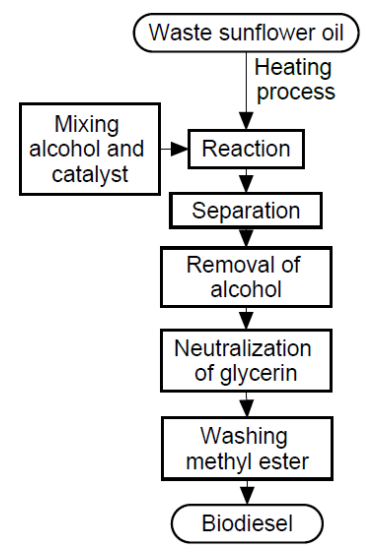

Fig. 1. Biodiesel production steps by transesterification method

For biodiesel production, a beaker, three inlet glass balloon, cooler, density measuring device, separating funnel, magnetic stirrer with thermocouple and sensitive scale are used. Technical properties of the materials used in biodiesel production are given in Table 1 and technical specifications of the devices are given in Table 2.
Table 1. Technical properties of materials used in biodiesel production

\begin{tabular}{c|c|c|c} 
Material name & $\begin{array}{c}\text { Waste sun- } \\
\text { flower oil }\end{array}$ & $\begin{array}{c}\text { Sodium hy- } \\
\text { droxide } \\
(\mathrm{NaOH})\end{array}$ & $\begin{array}{c}\text { Methyl al- } \\
\text { cohol } \\
\left(\mathrm{CH}_{3} \mathrm{OH}\right)\end{array}$ \\
\hline Density $\left(\mathrm{g} / \mathrm{cm}^{3}\right)$ & 0.922 & 2.13 & $0.790-0.793$ \\
\hline $\begin{array}{c}\text { Molecular weight } \\
(\mathrm{g} / \mathrm{mol})\end{array}$ & - & 40 & 32.04 \\
\hline Boiling point & - & - & $64-65$ \\
\hline Melting point & - & $319-322^{\circ} \mathrm{C}$ & - \\
\hline Resolution & $1090 \mathrm{~g} / \mathrm{l}$ & - & - \\
\hline Refractive index & - & - & $1.328-1.331$
\end{tabular}

Table 2. Technical properties of devices

\begin{tabular}{c|c|c|c} 
Device name & Brand / Model & Precision & $\begin{array}{c}\text { Maximum } \\
\text { values }\end{array}$ \\
\hline Precision scales & SHIMADZU & $\pm 0,001 \mathrm{~g}$ & $620 \mathrm{~g}$ \\
\hline $\begin{array}{c}\text { Magnetic stirrer } \\
\text { with heater }\end{array}$ & $\begin{array}{c}\text { Wisd Wis- } \\
\text { eStir/ MSH- } \\
\text { 20D }\end{array}$ & $\pm 0,3{ }^{\circ} \mathrm{C}$ & $\begin{array}{c}20 \\
\mathrm{~L} / 380{ }^{\circ} \mathrm{C}\end{array}$
\end{tabular}

In order to remove the particles in the waste sunflower oil, the sunflower oil is heated up to $80^{\circ} \mathrm{C}$ and filtered with the help of funnel and filter paper. In order to remove the water particles in the waste oil, the waste oil is kept at $120{ }^{\circ} \mathrm{C}$ for about 1 hour. The visualization of particle filtration of waste oil and removal of water particles is given in Fig. 2.

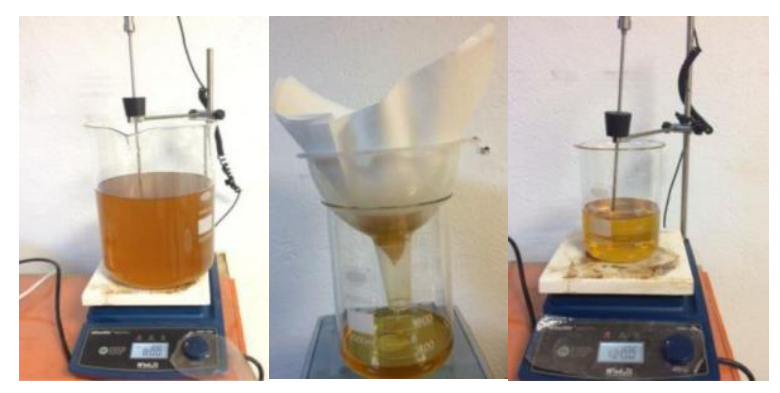

Fig. 2. Heating and filtration of waste sunflower oil and removal of water particles

Homogeneous catalyst was prepared and used due to the short production time and being more commercially viable. In order to achieve a homogeneous reaction, the solid $\mathrm{NaOH}$ was dissolved in methyl alcohol. As seen in Figure 3, methanol and sodium hydroxide are mixed in the flask until they dissolve with the help of magnetic stirring, and the formation of methoxide (sodium hydroxide-methanol solution) has occurred. After heating, which was carried out to remove water particles, biodiesel and methoxide, which dropped below $60{ }^{\circ} \mathrm{C}$, were added to the flask. During this process, a magnetic stirrer rotating at a speed of $600 \mathrm{rpm}$ was thrown into the balloon in order to ensure homogeneous reaction. Since the boiling temperature of methyl alcohol is about $64.7^{\circ} \mathrm{C}$, 


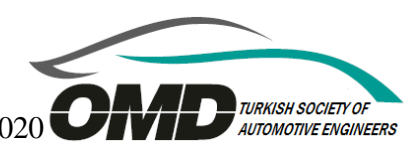

the temperature is limited to $60^{\circ} \mathrm{C}$ and evaporation of methyl alcohol is reduced to a minimum. The evaporated methyl alcohol was recycled to the system thanks to the cooling device located on the upper side of the balloon. The reaction process took approximately 1.5 hours.

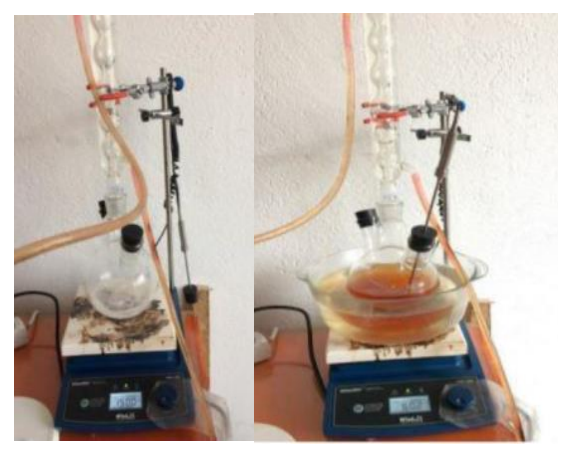

Fig.3. Methoxide formation and reaction setup

At the end of the reaction process, the mixture is left for about 10 hours of rest and the glycerin is separated from the biodiesel. Fatty acids, catalyst and unreacted alcohols in the biodiesel obtained as a result of the reaction are removed by washing. If these substances are not removed from biodiesel, it is likely to have an abrasive effect on engine parts with rubber or rubber connections during use. Approximately 11.5 times the biodiesel separated from glycerine is shaken by mixing with water at $80-100{ }^{\circ} \mathrm{C}$ in the separation funnel. During the rinsing process, the pressure of the container is opened and the pressure balancing is performed. At the end of the washing process, the separatory funnel is suspended and biodiesel and water are separated in two phases. The washing process is repeated periodically and continues until the color of the water becomes clear. In this study, an average of 5 washes was performed for each production. Separation of biodiesel and glycerin and washing process can be seen in Fig. 4.

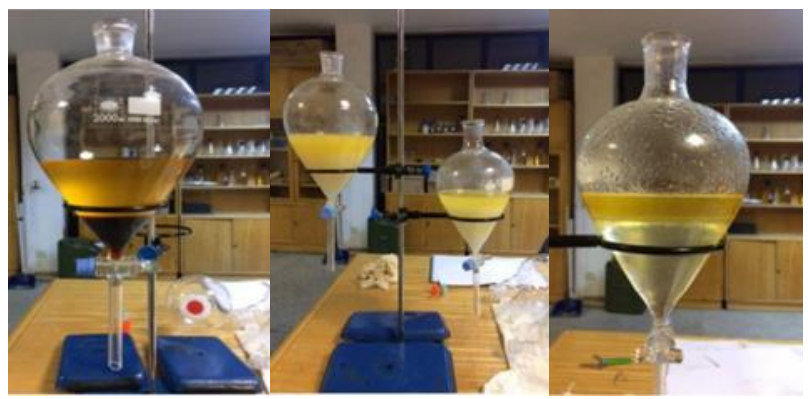

Fig.4. Separation of biodiesel and glycerin and washing process

After the biodiesel is subjected to the washing process, the drying process is applied to remove the water particles remaining in it. The drying process is noticed by the eye that the clarity of the biodiesel increases during the process. After drying, the biodiesel is stored under suitable conditions by filtering for the last time. The last filtering and storage of the biodiesel is shown in Fig. 5.

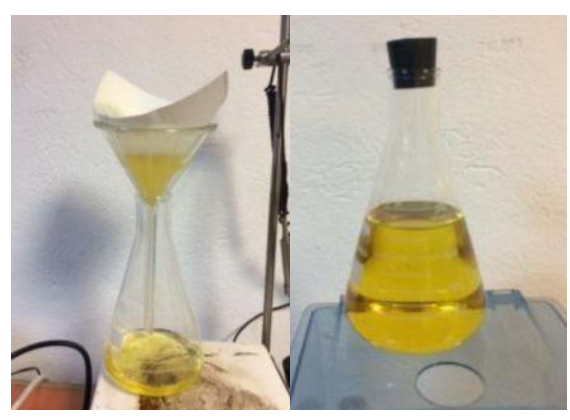

Fig.5. Filtering and storage of biodiesel

\subsection{Experimental setup}

The effect of biodiesel fuel obtained from waste sunflower oil on engine performance and specific fuel consumption was investigated. The schematic representation of the test setup in which experiments are carried out is shown in Fig 6. On the engine test device, there is a DC current operated dynamometer that can apply resistance at a maximum power of $10 \mathrm{~kW}$ at $4000 \mathrm{rpm}$. Technical characteristics of ANTOR 3 LD 510 single cylinder, four stroke diesel engine in the test setup are shown in Table 3. On the test panel, engine speed and engine moment can be precisely adjusted and kept stable throughout the testing process. The calculation of the fuel consumed by the engine during the test process can be measured with the help of precision scales and stopwatches.

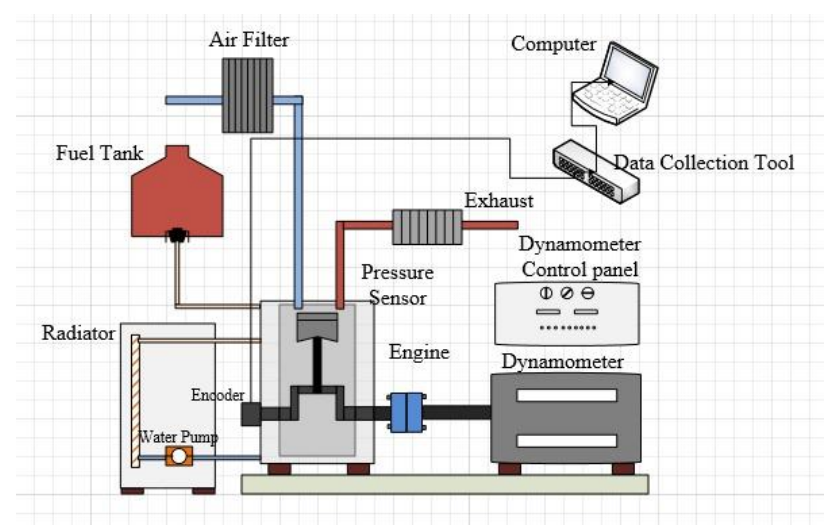

Fig.6. Experimental setup 
Table 3. Engine parameters

Engine Parameters

\begin{tabular}{c|c}
\hline Fuel System & Direct injection \\
\hline Number of cylinder & 1 \\
\hline Cylinder volume, $\left(\mathrm{cm}^{3}\right)$ & 510 \\
\hline Stroke, $(\mathrm{mm})$ & 90 \\
\hline Compression ratio & 17.5 \\
\hline Maximum engine speed, $(\mathrm{rpm})$ & 1800 \\
\hline Maximum engine moment $(\mathrm{Nm})$ & 23.6
\end{tabular}

The experiments of the produced B100 biodiesel fuel and standard diesel fuels were carried out under the full load conditions of the engine (4/4 throttle opening). Performance and fuel consumption tests were carried out at 7 different engine speeds, at 1800, 2000, 2200, 2400, 2600, 2800 and 3000 rpm, at full load conditions of the diesel engine. Before the experiment, engine coolant and oil levels were checked and the engine was brought to operating temperature. Firstly, performance and fuel consumption tests were performed with standard diesel fuel. In the next stage, performance and fuel consumption tests were carried out with pure biodiesel fuel obtained from waste sunflower oil.

\section{Results and Discussion}

Biodiesel fuel produced by the transesterification method was analyzed from waste sunflower oil. The properties of biodiesel fuel obtained as a result of the analysis are given in Table 4. The results obtained were compared with the values found in EN 14214 Biodiesel European Standards, and the density, kinematic viscosity, water content and sulfur content of the biodiesel fuel were found to be among the standard values. It is concluded that the produced biodiesel fuel meets the EN 14214 Biodiesel European Standards.

Table 4. Biodiesel parameters

\begin{tabular}{c|c} 
Fuel feature & Value \\
\hline Density, $(\mathrm{kg} / \mathrm{l})$ & 0.88413 \\
\hline Kinematic viscosity, $\left(\mathrm{mm}^{2} / \mathrm{s}\right)$ & 4.71 \\
\hline Sulfur content, $(\mathrm{ppm})$ & 2.4 \\
\hline Water content, $(\mathrm{ppm})$ & 265
\end{tabular}

Fig. 7 shows the viscosity values of biodiesel fuels obtained with different temperature, alcohol and catalyst ratios. According to the EN 14214 standard, the viscosity of the biodiesel must be in the range of 3.5 to $5 \mathrm{~mm}^{2} / \mathrm{s}$. When Figure 7 is analyzed, it is seen that biodiesel does not meet the standards when the catalyst ratio in $15 \%$ and $20 \%$ alcohol levels falls below $0.05 \%$ by mass. However, it is understood that by increasing the alcohol rate, the viscosity has reached the desired range. The minimum biodiesel fuel viscosity at $60{ }^{\circ} \mathrm{C}$ reaction temperature was obtained as $4,372 \mathrm{~mm}^{2} / \mathrm{s}$ with $25 \%$ alcohol and $0.05 \%$ catalyst ratio. It was determined that as the catalyst and alcohol ratio increased, the viscosity gradually decreased. However, excessive increase of catalyst amount in transesterification method causes high acidity of the produced biodiesel and $\mathrm{NO}_{\mathrm{x}}$ emissions to increase. The high amount of methanol makes it difficult to control the evaporated alcohol.

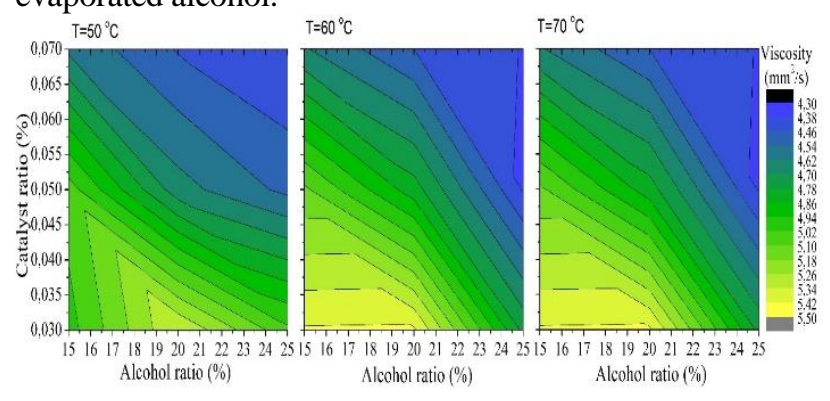

Fig.7. Viscosity values of biodiesel fuels obtained with different temperature, alcohol and catalyst ratios

The viscosity of the biodiesel produced as reaction temperature $60{ }^{\circ} \mathrm{C}$, alcohol and catalyst ratio $25 \%$ and $0.05 \%$, was obtained as $4,372 \mathrm{~mm}^{2} / \mathrm{s}$. Graphs showing the density values of biodiesel fuels obtained with different temperatures, alcohol and catalyst ratios are given in Fig. 8. It was concluded that the biodiesel fuel density decreases in almost all conditions when the catalyst ratio is increased in the fixed alcohol ratio. It is seen that in the fixed catalyst ratio, the density decreases when the alcohol rate increases.
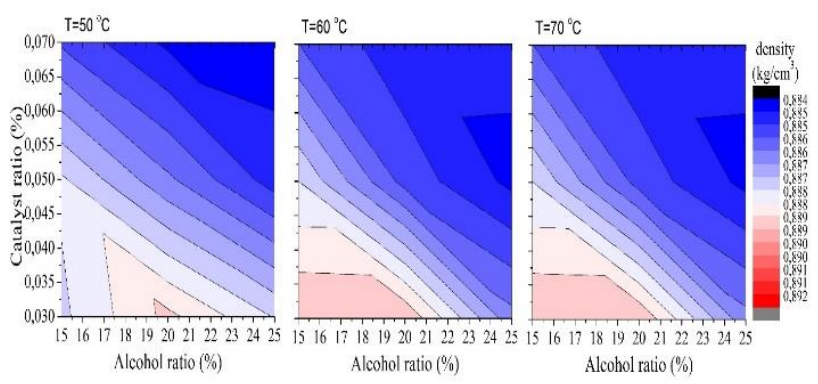

Fig. 8. Density values of biodiesel fuels obtained with different temperature, alcohol and catalyst ratios

Fig. 9 shows the water values of biodiesel fuels obtained with different temperature, alcohol and catalyst ratios. With the increase of the biodiesel reaction temperature, an increase in the water content was observed.

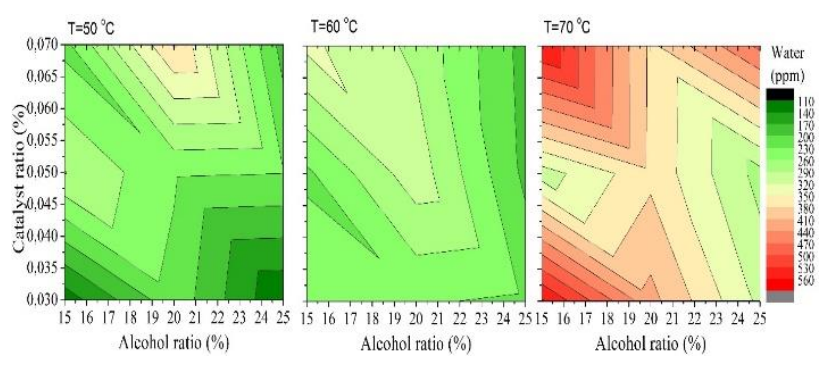

Fig. 9. Water values of biodiesel fuels obtained with different temperature, alcohol and catalyst ratios 
Figure 10 shows the change in engine moment and engine power depending on engine speed for B100 and diesel fuel. Using B100 fuel has reduced engine moment and engine power at all revs according to diesel use. It was observed that the engine torque increased for both fuel types by increasing the volumetric efficiency by increasing the engine speed from $1800 \mathrm{rpm}$ to $2200 \mathrm{rpm}$ and increasing the amount of fuel accordingly. At $2200 \mathrm{rpm}$ engine speed, the maximum moment value was obtained for diesel and B100 fuel as 20.16 $\mathrm{Nm}$ and $18.83 \mathrm{Nm}$, respectively. As a result of the use of B100 fuel, it was observed that the engine moment decreased by approximately $7.06 \%$ at maximum moment speed compared to diesel use. In addition, there was a $6.64 \%$ reduction in engine power compared to diesel fuel of B100 fuel. This is because the viscosity of the B100 fuel is higher than that of diesel fuel. Therefore, fuel B100 is sprayed into the combustion chamber in larger droplets. Evaporation and burning time are prolonged due to the large droplets. These delays in the combustion event cause the combustion event to sag into the expansion time, causing thermal efficiency and decreases in engine moment [6]. In addition, the heating value of B100 fuel is lower than diesel fuel. Low heating value causes engine power to drop.

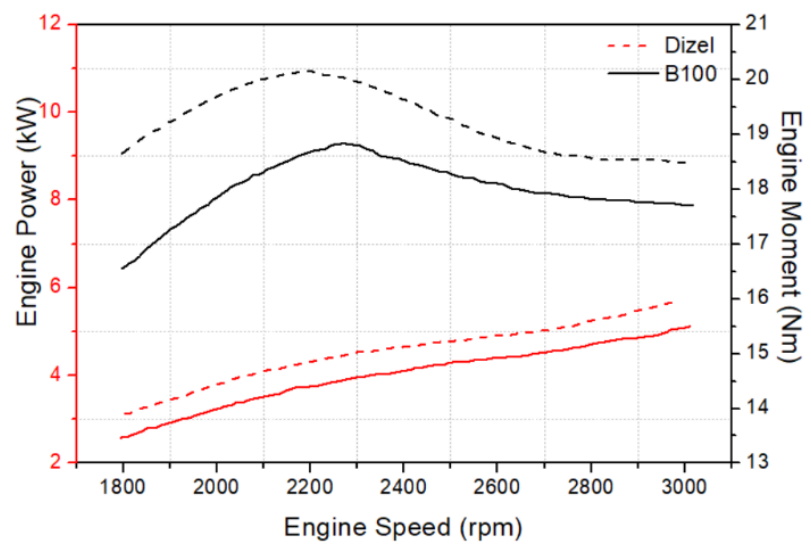

Fig. 10. Moment and power change according to engine speed

Fig. 11 shows the change in specific fuel consumption depending on engine speed. The use of B100 fuel increases its specific fuel consumption compared to the use of diesel fuel. The main reason for this increase in specific fuel consumption is that the heating value of B100 fuel is lower than that of diesel fuel. In this case, more B100 fuel should be sent to the combustion chamber in order to obtain the same engine power at the same speed. Specific fuel consumption values for B100 and diesel fuels at $2200 \mathrm{rpm}$ engine speed were $426.75 \mathrm{~g} / \mathrm{kWh}$ and $355.22 \mathrm{~g} / \mathrm{kWh}$, respectively. Using the B100 instead of standard diesel fuel under maximum engine speed conditions increased specific fuel consumption by $20.14 \%$. On the basis of all engine speed conditions, an increase of approximately $15.7 \%$ was observed in specific fuel consumption. In addition, there was a $6.64 \%$ decrease in engine power compared to diesel fuel of B100 fuel.

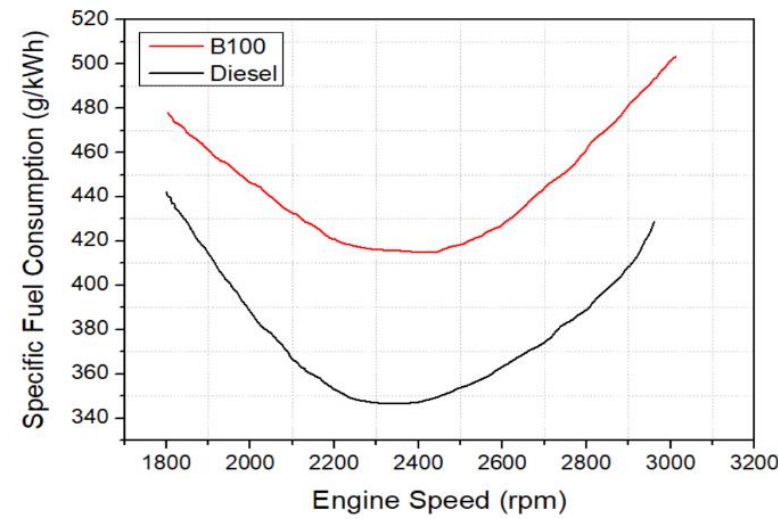

Fig. 11. Change of specific fuel consumption according to engine speed

\section{Conclusions}

In this study, biodiesel production and engine performance tests were performed from waste sunflower oil. It is produced by using biodiesel transesterification method. The viscosity of the biodiesel produced as reaction temperature $60{ }^{\circ} \mathrm{C}$, alcohol and catalyst ratio $25 \%$ and $0.05 \%$, was obtained as $4,372 \mathrm{~mm}^{2} / \mathrm{s}$. It is concluded that the produced biodiesel complies with EN 14214 Biodiesel European Standards. With the increase of the biodiesel reaction temperature, an increase in the water content was observed.

Comparison of produced biodiesel fuel with standard diesel fuel. It was observed that there was a $7.06 \%$ reduction in engine moment compared to the standard diesel fuel usage of B100 fuel. In addition, there was a $6.64 \%$ reduction in engine power compared to diesel fuel of B100 fuel. Specific fuel consumption values for B100 and diesel fuels at 2200 $\mathrm{rpm}$ engine speed were $426.75 \mathrm{~g} / \mathrm{kWh}$ and $355.22 \mathrm{~g} / \mathrm{kWh}$, respectively.

\section{References}

[1] Faried, M., Samer, M., Abdelsalam, E., Yousef, R. S., Attia, Y. A., Ali, A. S. (2017). Biodiesel production from microalgae: Processes, technologies and recent advancements. Renewable and sustainable energy reviews, 79, 893-913.

[2] Sekhar, S. C., Karuppasamy, K., Vedaraman, N., Kabeel, A. E., Sathyamurthy, R., Elkelawy, M., Bastawissi, H. A. E. (2018). Biodiesel production process optimization from Pithecellobium dulce seed oil: Performance, combustion, and emission analysis on compression ignition engine fuelled with diesel/biodiesel blends. Energy conversion and management, 161 141-154.

[3] Mahlia, T. M. I., Syazmi, Z. A. H. S., Mofijur, M., Abas, A. P., Bilad, M. R., Ong, H. C., Silitonga, A. S. (2020). Patent landscape review on biodiesel production: Technology updates. Renewable and Sustainable Energy Reviews, 118, 109526.

[4] Veljković, V. B., Biberdžić, M. O., Banković-Ilić, I. B., Djalović, I. G., Tasić, M. B., Nježić, Z. B., Stamenković, O. S. 
(2018). Biodiesel production from corn oil: A review. Renewable and Sustainable Energy Reviews, 91, 531-548

[5] Özdemir, Z. Ö., Mutlubaş, H.(2016). Biyodizel üretim yöntemleri ve çevresel etkileri, Kırklareli Üniversitesi Mühendislik ve Fen Bilimleri Dergisi, 2, 129-143,

[6] Uyumaz, A., Aksoy, F., Boz, F., Y1lmaz, E. (2017). Experimental investigation of neutralized waste cooking oil biodiesel and diesel fuels in a direct injection diesel engine at different engine loads. International Journal of Automotive Science and Technology, 1, 7-15.

[7] Aydin, M., Afsar, M., Çelik, M. B. (2016). Tek silindirli bir dizel motorda atık biyodizel kullanımının motor performans1 ve emisyonlarına etkisi. In 4th International Symposium On Innovative Technologies In Engineering And Science (ISITES2016), 3-5 Nov 2016 Alanya/Antalya-Turkey.

[8] Mofijur, M., Rasul, M. G., Hyde, J. (2015). Recent developments on internal combustion engine performance and emissions fuelled with biodiesel-diesel-ethanol blends. Procedia Engineering, 105, 658-664.

[9] Alvarez, J., Lopez, G., Amutio, M., Mkhize, N. M., Danon, B., Van der Gryp, P., Olazar, M. (2017). Evaluation of the properties of tyre pyrolysis oils obtained in a conical spouted bed reactor. Energy, 128, 463-474.

[10]Özener, O., Yüksek, L., Ergenç, A. T., Özkan, M. (2014). Effects of soybean biodiesel on a DI diesel engine performance, emission and combustion characteristics. Fuel, 115, 875-883.

[11]Kumar, P., Rehman, A. (2016). Bio-diesel in homogeneous charge compression ignition (HCCI) combustion. Renewable and Sustainable Energy Reviews, 56, 536-550.

[12]Giakoumis, E. G., Rakopoulos, C. D., Dimaratos, A. M., Rakopoulos, D. C. (2012). Exhaust emissions of diesel engines operating under transient conditions with biodiesel fuel blends. Progress in Energy and Combustion Science, 38, 691715 .

[13]Aksoy, L. (2010). Alternatif enerji kaynağı olarak biyodizel ve üretim prosesleri. Taşıt Teknolojileri Elektronik Dergisi, 2, 4552.

[14]Uyumaz, A., Solmaz, H., Y1lmaz, E., Yamık, H., Polat, S. (2014). Experimental examination of the effects of military aviation fuel JP- 8 and biodiesel fuel blends on the engine performance, exhaust emissions and combustion in a direct injection engine. Fuel Processing Technology, 128, 158-165.

[15]Pullen, J., Saeed K. (2014). Factors affecting biodiesel engine performance and exhaust emissions, Energy, 1-16.

[16]Akay, F. (2017). Atık zeytinyağindan elde edilen biyodizelin motor performansi ve egzoz emisyonlarina etkileri, Yüksek Lisans Tezi, Afyon Kocatepe Üniversitesi Fen Bilimleri Enstitüsü, Afyon.

[17]Hasan, M. M., Rahman, M.M. (2017). Performance and Emission Characteristics of Biodiesel-diesel Blend and Environmental and Economic Impacts of Biodiesel Production: A Review, Renewable and Sustainable Energy Reviews, 74, 938948.

[18]Çat, S. (2012). Dizel motorda atik biyodizel kullaniminin performans ve emisyonlara etkisi, Yüksek Lisans Tezi, Karabük
Üniversitesi Fen Bilimleri Enstitüsü, Karabük.

[19]Soysal, C. (2008). Dizel motorlarinda biyodizel-dizel yakiti karişimlarinin kullanilmasinin motor performansina etkisinin deneysel olarak incelenmesi, Yüksek Lisans Tezi, Karadeniz Teknik Üniversitesi Fen Bilimleri Enstitüsü, Trabzon.

[20]Nişanc1, S. (2007). Biyodizel yakit karişimlarinin performans ve emisyon üzerine etkilerinin deneysel araştirilmasi, Yüksek Lisans Tezi, Yıldız Teknik Üniversitesi Fen Bilimleri Enstitüsü, İstanbul.

[21]Özsezen, A. N. (2007). Atık palmiye yağindan üretilen biyodizelin motor performans ve emisyon karakterleri üzerine etkisinin incelenmesi, Yayınlanmış Doktora Tezi, Kocaeli Üniversitesi Fen Bilimleri Enstitüsü, Kocaeli.

[22]Dinçbaş, A. (2007). Biyodizel kullaniminin dizel motoru üzerindeki etkilerinin uzun süreli testlerle ve motorinle karşilaştirmali olarak incelenmesi, Yüksek Lisans Tezi, Ege Üniversitesi Fen Bilimleri Enstitüsü, İzmir.

[23]Kaya, M. (2010). Biyodizel-dizel karişimi kullanilan bir dizel motorda püskürtme basincinin performans ve emisyonlara etkisi, Yüksek Lisans Tezi, Marmara Üniversitesi Fen Bilimleri Enstitüsü, İstanbul.

[24]Alptekin, E., Çanakçı, M., Özsezen, A. N., Türkcan, A., Şanlı, H. (2015). Using waste animal fat based biodiesels-bioethanol-diesel fuel blends in a DI diesel engine, Fuel, 157: 245254.

[25]Tillem, İ. (2005). Dizel Motorlar İçin Alternatif Yakıt Olarak Biyodizel Üretimi ve Kullanımı, Yüksek Lisans Tezi, Pamukkale Üniversitesi Fen Bilimleri Enstitüsü, Denizli. 